\title{
RELASI INTERPERSONAL DALAM PSIKOLOGI KOMUNIKASI
}

\author{
Rustini Wulandari, Amelia Rahmi \\ Jurusan Komunikasi dan penyiaran islam UIN Walisongo \\ Email :rustiniwulandari@gmail.com, ameliarahmi@walisongo.ac.id
}

\begin{abstract}
( urvival of human life is proof that human being able to solve and fulfill requirements of life which is individual and also social. Human life is a building interpersonal relationship with each other, called interpersonal relationship. The more an active person building relationships with others it will build an extensive interpersonal network and produce quality self-competence. This is what can bring success in many ways. Generally humans can adjust to the situation faced by learning the previous experience. Overtime the relationship develops an individual character. The psychological aspect of both parties involved in the relationship are more decesive compared with sociological and cultural aspects. The existence of psychological aspect that determine the process of interpersonal communication has led to a specific study in interpersonal relationships into studies in this article, although the study has not been based on in-depth research.
\end{abstract}

Keywords: communication, psychology, interpersonal relationship

\begin{abstract}
ABSTRAK
$\mathrm{K}$ elangsungan hidup manusia di muka bumi hingga kini merupakan bukti bahwa manusia mampu menyelesaikan dan memenuhi kebutuhan yang bersifat individu dan sekaligus sosial.Kehidupan ini merupakan bangunan relasi antarpersonal satu dengan yang lainnya, disebut relasi interpersonal. Semakin seseorang aktif membangun relasi dengan sesama maka akan terbangun jaringan interpersonal yang luas dan menghasilkan kompetensi diri yang berkualitas. Hal inilah yang dapat membawa kesuksesan dalam banyak hal.

Umumnya, manusia dapat menyesuaikan dengan situasi yang dihadapi dengan cara mempelajari pengalaman sebelumnya. Seiring dengan waktu hubungan berkembanglah sebuah karakter individu. Aspek-aspek psikologis yang dimiliki kedua belah pihak yang terlibat dalam relasi lebih menentukan dibanding dengan aspek sosiologis dan kultural.Adanya aspek psikologis yang menentukan proses komunikasi interpersonal telah memunculkan kajian spesifik dalam relasi interpersonal menjadi kajian dalam artikel ini, meskipun kajiannya belum berbasis riset secara mendalam
\end{abstract}

Kata kunci: komunikasi, psikologi, relasi interpersonal. 


\section{PENDAHULUAN}

Tidak ada manusia yang bisa berkembang dengan baik tanpa dia memiliki kesempatan berhubungan dan bekerjasama dengan manusia lain. Hubungan dan kerjasama menjadi sesuatu yang hampir pasti disetiap kehidupan seorang manusia dimanapun dia berada. Dengan cara tersebut kemudian menjadikan manusia saling tergantung untuk kelangsungan dan perkembangannya. Menarik membaca salah satu hasil riset Antar Venus setelah meneliti masyarakat Melayu yang menjelaskan tentang sistem keyakinan orang Melayu, bahwa hidup diartikan sebagai kerjasama antarmanusia yang bersifat saling bergantung. Bahwa manusia menjalani dan membangun hidup dengan saling berhubungan dan bergantung satu dengan yang lainnya. Membangun hubungan bisa dikatakan merupakan suatu kegiatan manusia yang tak terhindarkan demi kelangsungan hidup manusia itu sendiri.(Venus.2015:41)

Kelangsungan hidup manusia di muka bumi hingga saat ini merupakan bukti bahwa manusia mampu menyelesaikan dan memenuhi kebutuhan hidup yang bersifat individual dan sekaligus sosial. Dengan akal dan budi yang dimiliki manusia melakukan upaya bertahan dan lalu berkembang, baik secara pribadi maupun kolektif. Pemenuhan kebutuhan manusia, baik yang bersifat individual dan sosial, primer maupun sekunder, bersifat dinamis sesuai dengan konteks ruang maupun waktu.

Manusia merupakan makhluk sosial, yang kehidupannya tidak bisa melepaskan diri dari bantuan dari yang lainnya. Dalam memenuhi kebutuhan hidupnya yang paling mendasar hingga sekunder membangun relasi dengan yang lainnya, sehingga kehidupan manusia merupakan bangunan relasi antar personal satu dengan yang lainnya. Relasi manusia satu dengan yang lainnya lebih dikenal dengan relasi interpersonal. Semakin seseorang membangun relasi dengan sesamanya maka akan terbangun suatu jaringan interpersonal yang luas. Kesatuan dari beragam personal yang dibangun akan memunculkan kelompok. Dinamika kelompok sangat ditentukan oleh beragam kebutuhan dan atau kepentingan personal yang terlibat di dalamnya.

Kokohnya relasi interpersonal sangat ditentukan oleh stimulan yang diungkapkan oleh seseorang sebagai suatu kebutuhan atau kepentingannya dengan respon yang muncul dari pihak lain yang menjadi sasaran kebutuhannya. Proses tersebut direproduksi terus menerus sehingga relasi interpersonal bisa berlangsung dengan baik. Kondisi atau perasaan saling membutuhkan merupakan energi yang memperkuat relasi tersebut. Selain itu ada upaya dari masing masing pihak untuk menjaganya, meskipun 
kadang ada perbedaan - perbedaan kebutuhan atau kepentingan. Adanya kebutuhan atau kepentingan yang harus terpenuhi seseorang seringkali harus menekan perbedaan yang muncul.

Relasi interpersonal yang terkelola dengan baik akan menghasilkan kompetensi diri yang berkualitas dalam kehidupan seseorang. Banyak ahli komunikasi hingga psikologi berpandangan bahwa kompetensi diri seseorang dalam relasi interpersonalnya akan membawa kesuksesan dalam banyak hal. Hayes (2006) berdasarkan hasil penelitiannya menemukan hal yang membedakan seorang manager yang sukses dan tidak sukses berdasarkan kompetensi interpersonal (Idrus. 2009: 171). Terkait kesuksesan dalam hidup dan karier pekerjaan Suchy (2000) berpandangan bahwa $80 \%$ faktor kompetensi relasi interpersonal menentukan efektivitas kehidupan seseorang dan pekerjaannya.

Kompetensi relasi interpersonal seseorang merupakan bagian penting faktor psikologis seseorang. Daniel Coleman memasukkannya dalam salah satu aspek konstruksi kecerdasan emosional. Aspek konstruksi kecerdasan emosional lainnya adalah: kesadaran diri, mengelola emosi, memanfaakan secara produktif, dan empati. (Wahyuni.2011:2) Tingkat kompetensi relasi interpersonal seseorang bisa dilihat pada kemampuannya menciptakan dan memelihara atau merawat hubungan dengan orang lain (antarpribadi) dengan baik dan memuaskan. Indikator tersebut melekat didalamnya karakteristik psikologis. (Idrus.2009:172)

Secara psikologis individu - individu yang terlibat dalam relasi interpersonal akan memperoleh keuntungan. Hadirnya orang lain dalam kehidupan seseorang akan bisa menjadi sarana merefleksi diri dengan bercermin dan atau mendapatkan penilaian dari orang lain. Relasi interpersonal seorang individu memungkinkannya untuk lebih bisa mengekspresikan beban dan kebutuhan psikologisnya yang tidak bisa diselesaikan dan dipenuhi sendiri. Dalam relasi tersebut individu akan lebih bisa mengembangkan potensi diri secara psikis dan sosial. Kuatnya relasi interpersonal memberikan peluang bagi individu berbagi beban kehidupannya dengan orang lain, karena adanya kepercayaan terbangun. Ada hubungan timbal balik diantara individu dalam hal menghadapi persoalan kehidupannya. Ketika salah satu pihak menghadapi masalah, maka bisa minta bantuan pihak lain sebagai saudara atau sahabat. Begitu pula sebaliknya individu akan menolong pihak lain yang menghadapi masalah. Oleh karena itu relasi interpersonal merupakan kebutuhan sosial yang primer bagi setiap individu sehingga akan bisa mencapai kebahagiaan dan 
penyangga terhadap tekanan hidup yang bisa membikin stress.

Tulisan ini mencoba mendeskripsikan pentingnya pemahaman psikologi untuk membangun relasi interpersonal yang merupakan suatu kebutuhan hidup primer manusia agar dengannya manusia mampu mencapai aktualisasi diri sesungguhnya.

\section{Konsep Dasar dan Prasyarat Relasi Interpersonal}

Relasi interpersonal merupakan hubungan antarpribadi yang berlangsung melalui tahapan interaksi awal sampai ke pemutusan. Hubungan antarpribadi memiliki perbedaan pada tingkat keluasan (breadth) dan tingkat kedalamannya (depth). (De Vito.1997:232). Pengembangan relasi interpersonal melalui beberapa tahapan, sehingga tidak terjadi secara instan. Setiap tahapan yang dicapai atau dilalui memberikan gambaran tentang tingkat keluasan dan kedalaman. Keberlangsungan relasi interpersonal ditentukan pula oleh tahap pengembangannya.

Relasi interpersonal merupakan relasi antar pribadi yang terjadi diantara dua atau lebih individu. Relasi interpersonal bisa terbangun melalui proses sosial yang melibatkan dua atau lebih individu. Masing - masing pihak tentu memiliki kontribusi sesuai dengan kapasitas membangun relasi dan kepentingan yang diharapkan dalam berelasi. Ada beberapa tahapan dalam pembentukan relasi interpersonal sebagai

proses sosial. Tahapan - tahapan tersebut merupakan pergerakan dari relasi positif hingga negatif. De Vito (1997: 233-235) menjelaskan tahapan komunikasi interpersonal sebagai proses psikologi komunikasi yang melibatkan aspek emosi dalam pembentukannya. Tahapan - tahapan tersebut meliputi;

1. Kontak: merupakan tahapan awal dalam relasi interpersonal dengan memanfaatkan alat indera mempersepsi orang lain dan membuat keputusan melanjutkan hubungan atau tidak. Penampilan fisik menjadi indikator dalam melihat terjadinya kontak, karena terlihat dengan mudah dan jelas. Kualitas kontak bisa ditemukan berdasar kondisi adanya persahabatan, kehangatan, keterbukaan dan dinamis.

2. Keterlibatan: merupakan tahapan pengenalan lebih jauh pada orang yang telah terbangun kontak. Seseorang menjadi lebih kenal diri orang lain dan mengungkap kediriannya. Jika hubungan tersebut dalam bentuk asmara maka akan ada kencan. Kalau bentuknya persahabatan maka akan melakukan sesuatu secara bersama sama karena memiliki minat yang sama.

3. Keakraban: merupakan tahapan yang membentuk hubungan yang mengikat antar pribadi. Hubungan pada tahapan 
ini disebut sebagai hubungan primer.

Kekasih dan atau sahabat merupakan bentuk nyata dari hubungan tahap ini. Seseorang akan dengan mudahnya membantu orang lain (sahabat) dan mengungkapkan rahasia dirinya yang terbesar.

4. Perusakan: tahapan ini terjadi ketika adanya penurunan hubungan antar seseorang ditandai dengan melemahnya ikatan hubungan, menjauh dan merasa hubungan tersebut tidaklah sepenting seperti saat hubungan terbentuk dan berlangsung sebelumnya.

5. Pemutusan: merupakan kondisi yang menunjukkan terputusnya tali pengikat hubungan. Prosesnya berawal dari peredaan, ketegangan, keresahan, saling tuduh, permusuhan, dan marah marah, kemudian memutuskan hubungan. Dalam perkawinan berupa perceraian dan atau hidup terpisah. (Abadi, dkk.2013:99)

Berikut gambaran/skema tahapan proses relasi interpersonal, antara dua pribadi, yaitu A dan $\mathrm{Z}$ yang bergerak dari arah kiri menuju pada arah kanan, dari seorang individu A kepada individu lain B

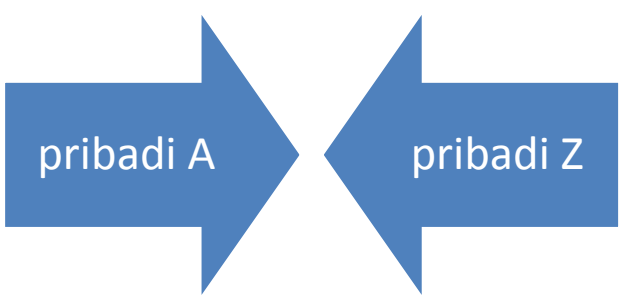

Adapun tahap hubungan melalui kontak dan berakhir pada pemutusan hubungan digambarkan sebagai berikut:

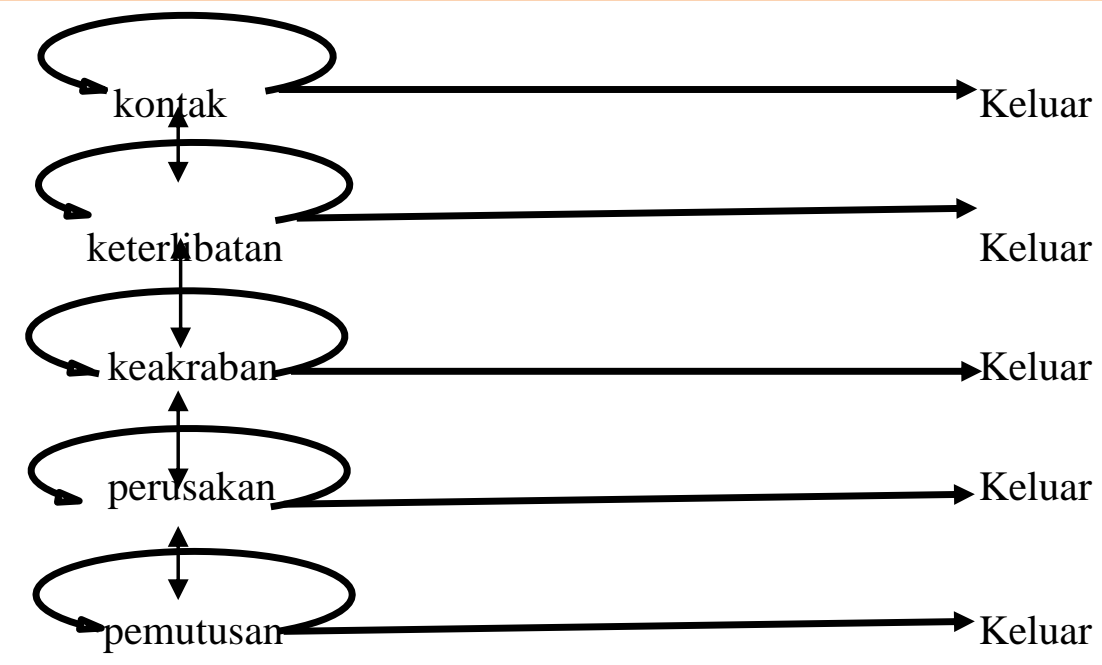


Pada tahap kontak, individu membuat membuat persepsi terhadap individu lain menggunakan alat indra berupa: penglihatan, pendengaran, dan penciuman. Hasil dari penggunaan alat indra akan terakumulasi informasi yang membangun persepsi individu atas individu lain. Jika persepsinya positif ada kemungkinan relasi terbangun atau berlanjut, tetapi sebaliknya kalau persepsinya negatif ada kemungkinan relasi terputus atau tidak berlanjut. Adanya kontak yang terbentuk relasi interpersonal akan berlanjut dalam bentuk keterlibatan. Pada tahapan ini maka ada proses pengenalan yang melibatkan diri diantara individu untuk saling mengenal lebih jauh. Dalam rangka membangun keterlibatan yang saling mengikat maka individu melakukan upaya pengungkapan diri (self disclosure). Pengungkapan diri merupakan inti dari perkembangan hubungan (Altman \& Taylor, 2006). Ada beragam sarana atau media untuk proses pengungkapan diri diantara individu yang membangun relasi interpersonal ( bermain, makan bersama, kegiatan sosial dan lain - lainnya).

Dalam tahapan pengembangan relasi interpersonal menawarkan suatu kemungkinan untuk keluar dari relasi yang telah terbentuk. Peluang seseorang untuk keluar dari hubungan dilatarbelakangi oleh beragam pertimbangan, misalnya: merasa sudah cukup berhubungan, hubungan mengandung resiko, hubungan tidak menguntungkan, dan kondisi yang tidak memungkinkan. Tahapan relasi interpersonal memberikan kesempatan pada pribadi yang mengembangkan hubungan untuk melakukan perpindahan atau loncatan dari satu tahapan ke tahapan lainnya. (De Vito. 1997: 235) Perpindahan tahapan sesuai dengan kebutuhan pribadi masing - masing. Tingkat keluasan dan kedalaman relasi bisa menjadi pertimbangan untuk berpindah.

Dalam relasi interpersonal setidaknya terhubung tiga aspek berikut: konsep diri, hubungan dan tindakan. Ketika individu masuk ke dalam sebuah interaksi maka seperti apa manusia dengan konsep diri yang dia miliki dapat berhubungan dengan pribadi yang lain. Seperti apa hubungan/relasi tersebut? Selanjutnya , tindakan apa yang mungkin terjadi dalam hubungan mereka?

Adanya banyak teori untuk menjelaskan tentang relasi interpersonal dalam masyarakat. Diantaranya psikologi common sense Heider (1958). Gagasan teori ini menganut metode konstruksi dari Lewin. Basis teori ini adalah istilah seharihari yang digunakan orang awam. Dinamika perilaku manusia berlangsung atas dasar common-sense (logika berpikir sehari-hari). Logika sehari - hari mengatur tingkah laku orang terhadap orang lain dan mengandung banyak kebenaran. Ada beberapa tingkah laku yang terjadi dalam 
relasi interpersonal menurut teori ini, seperti: mengamati orang lain, orang lain sebagai pengamat, analisis sederhana terhadap tindakan orang, kausalitas personal dan impersonal, hasrat dan kesenangan' sentimen, keharusan dan nilai, permintaan dan perintah, keuntungan dan kerugian, dan reaksi terhadap pengalaman orang lain.

Relasi interpersonal akan bisa berlangsung dengan baik jika proses komunikasi antar personal yang terlibat berlangsung dengan baik. Proses komunikasi antar pihak akan lancar jika didukung dengan penggunaan bahasa yang bisa diterima atau dipahami. Bahasa yang digunakan dalam komunikasi yang menjadi dasar relasi interpersonal, bisa bahasa lisan, tulisan, dan bahasa isyarat. Pihak yang terlibat dalam relasi interpersonal bisa memilih atau menggunakan salah satu, atau semuanya. Penggunaannya menyesuaikan dengan kondisi internal dan eksternal pihak - pihak yang terlibat. Dalam praktiknya, relasi interpersonal bisa terjadi pada konteks formal maupun non formal, bisa urusan individu maupun kolektif.

Aminuddin Nurdin (seorang praktisi komunikasi bidang komunikasi perusahaan di PT Astra Internasional Tbk) merupakan salah satu contoh orang yang mencapai relasi interpersonal yang sukses. Seperti dikemukakan T.P. Rachmat (founder Triputra Group) berikut:” Tidak banyak yang bisa bertahan di satu bagian selama berpuluh-puluh tahun dan mampu menapak karier hingga menduduki jabatan setingkat direksi. Pak Aminuddin adalah salah satunya yang bisa melakukan itu. Ini bisa dicapai karena beliau punya integritas tinggi, mudah bergaul, dapat diterima semua pihak, bisa bekerja sama, punya network yang luas, serta memahami kebutuhan dan keinginan direksi, komisaris dan pemegang saham".(Nurdin.2016:iii). Demikianlah, relasi interpersonal yang dilakukan dengan mengkombinasikan kemampuan berkomunikasi, mampu bekerja sama,dan dengan integritas yang tinggi dapat menghantarkan pada kesuksesan.

Saat ini nama Aminuddin Nurdin tak dapat disangkal, meminjam istilah dari Ahmad Djauhar (Wakil Pimpinan Umum Harian Bisnis Indonesia), merupakan salah satu praktisi, pakar, sekaligus guru di bidang public relations yang namanya sangat dikenal di Indonesia. Aminuddin juga aktif di organisasi ASPIKOM dengan posisi Dewan Penasehat. Tokoh inilah (Aminuddin Nurdin) yang mendesain dan mengembangkan subgenre di bidang corporate Public Relations di negeri ini, dengan keberhasilannya antara lain mengawal bidang kehumasan PT Astra Internasional Tbk lebih dari tiga (3) dekade. 
Barangkali kesuksesan Aminuddin juga karena latar belakang beliau sebagai seorang Minangkabau. Dalam kebudayaan Minang, menjadi manusia yang telah dewasa terukur dan teruji jika sudah mencapai tingkat kearifan dalam hidup. Kearifan yang dimiliki makin teruji saat bergaul dalam lingkungan luas, jika sudah saling memahami dan mengasah keterampilan daya pikir dalam mengolah dan mencerna hidup. Sifat mudah bergaul dan mudah beradaptasi yang dimiliki orang Minang memperlancar hubungan dengan lingkungan baru.. Mereka pandai menilai dan mengetahui bagaimana cara bersikap terhadap seseorang dan suatu lingkungan tempat mereka menetap. Dengan kemampuan relasi interpersonal tersebut banyak orang Minang sukses ditempat perantauannya. (Nurdin. 2016:12)

Dalam proses komunikasi interpersonal penggunaan bahasa sebagai simbol atau signal memiliki aturan atau kaidah - kaidah tertentu, yang kedua belah pihak saling memahami. Pemahaman atas aturan menjadikan orang yang menerima signal yang terkirim atau disampaikan pada akan mendapat respon yang sesuai. Karena pihak lain memahami signal tersebut sesuai aturan yang telah diketahuinya. Kondisi sebaliknya bisa terjadi ketika si penerima tidak dapat memahami maksud dari signal tersebut, maka dia tidak dapat merespon sesuai keinginan pihak yang menyampaikan signal.(Muhammad.1995:23)

Relasi interpersonal akan berifat positif dan berlangsung secara efektif jika berlangsung melalui proses komunikasi yang efektif. Dalam studi Ilmu Komunikasi dijelaskan bahwa komunikasi yang efektif bisa dilihat pada out come (hasilnya), ada beberapa hasil komunikasi sebagai indikator efektifitas (Tubbs dan Moss. 1996:22-28) :

\section{Pengertian atau pemahaman}

Pengertian artinya penerimaan yang cermat dari isi stimuli seperti yang dimaksud oleh komunikator. Kegagalan menerima isi pesan secara cermat disebut kegagalan komunikasi primer (primary breakdown in communication). Komunikasi yang gagal bisa disebabkan pihak yang berkomunikasi mengalami kesalahpahaman atau pengertian yang tidak sesuai dengan yang diharapkan. Komunikasi yang efektif adalah komunikasi yang menimbulkan pemahaman atau pengertian atas sesuatu yang disampaikan dalam berkomunikasi (pesan).

\section{Kesenangan}

Komunikasi yang efektif ditandai oleh terciptanya situasi yang menyenangkan diantara pihak - pihak yang terlibat di dalamnya atau pun lingkungannya. Istilah yang lebih khusus untuk menunjuk kondisi ini adalah komunikasi fatis (phatic communication). Terciptanya situasi yang 
menyenangkan akan membuat relasi interpersonal akan semakin hangat, dan akrab. Individu - individu menjadi tidak ada beban untuk mengekspresikan keinginan, kebutuhan, kepentingannya dan perasaannya dalam relasi interpersonal.

3. Mempengaruhi Sikap

Komunikasi yang efektif akan mampu mempengaruhi sikap dari pihak yang menerima pesan (komunikan). Adanya perubahan sikap mengindikasikan pesan bisa diterima dan dipahami. Perubahan sikap menunjukkan respon timbal balik komunikan terhadap komunikator. Perubahan sikap menunjukkan pula keberhasilan komunikasi persuasif. Persuasi merupakan proses mempengaruhi pendapat, sikap, dan tindakan dengan menggunakan manipulasi psikologis sehingga orang tersebut bertindak seperti atas kehendaknya sendiri.

4. Hubungan Sosial Yang Baik
Komunikasi yang efektif akan menciptakan relasi interpersonal yang bersifat hubungan sosial yang baik diantara individu yang terlibat di dalamnya sebagai relasi interpersonal. Implikasi yang lebih akan menciptakan lingkungan sosial yang lebih harmonis atau damai. Konflik sosial akan bisa terminimalisir, karena perbedaan - perbedaan yang terjadi bisa dikelola dengan baik.

\section{Tindakan}

Tindakan merupakan bentuk ungkapan kehendak seseorang dalam dunia nyata yang berimplikasi pada dirinya dan orang lain. Setiap orang menghendaki segala tindakan sesuai dengan tujuan yang dikehendaki dan tidak menimbulkan efek negatif pada orang lain. Komunikasi yang efektif membantu seseorang atau individu mewujudkan keduannya. enting. Tidakan seseorang yang positif merupakan ungkapan dari pemahamannya atas sesuatu, sikap dan pandangannya.

Indikator komunikasi efektif secara jelas tergambar sebagai berikut:

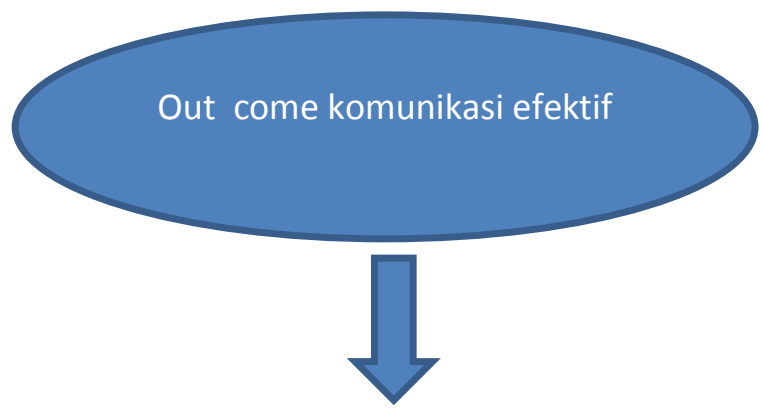




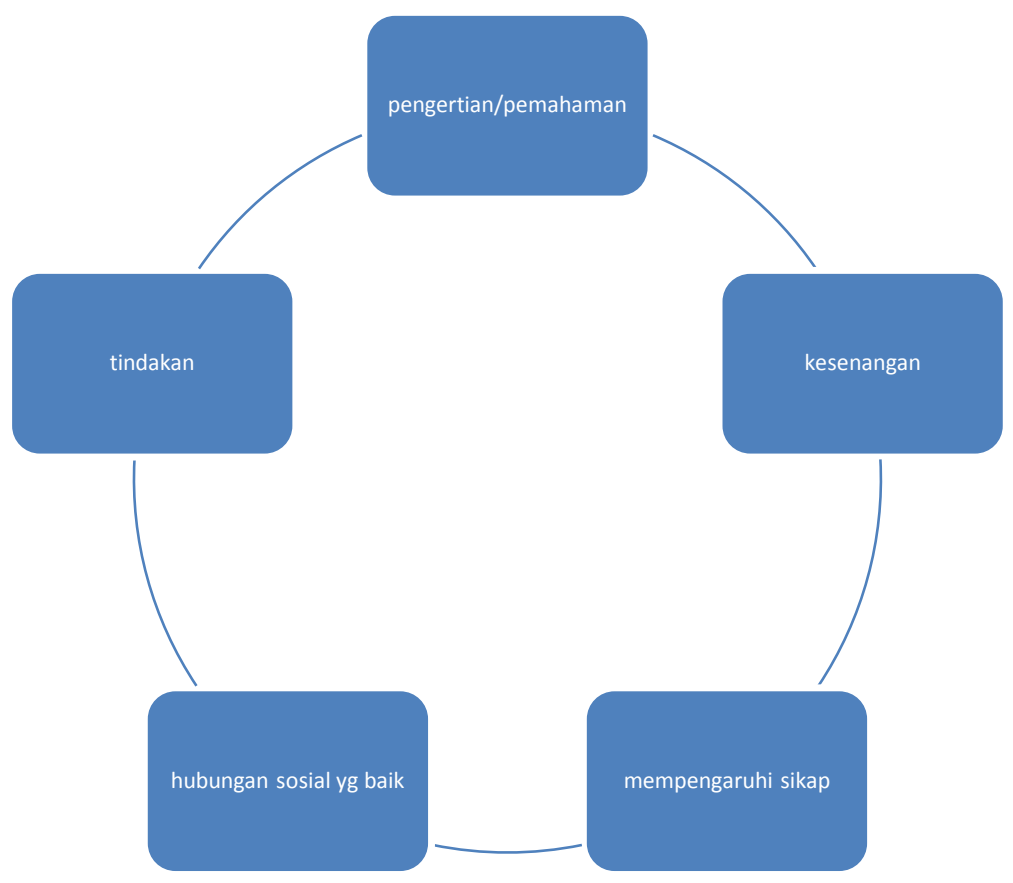

\section{Pentingnya Relasi Interpersonal Dalam Masyarakat}

Manusia merupakan makhluk sosial yang hidupnya membutuhkan dan dibutuhkan orang lain. Relasi interpersonal menjadi sarana bagi terciptanya kondisi hubungan timbal balik untuk pemenuhan kebutuhan manusia dalam lingkungan sosialnya. William Schutz merinci kebutuhan kebutuhan sosial dan psikologis manusia dalam kehidupan sosialnya dalam tiga: kebutuhan untuk menumbuhkan dan mempertahankan hubungan yang memuaskan dengan orang lain dalam hal interaksi dan asosiasi (inclusion), pengendalian dan kekuasaan (control), cinta serta rasa kasih sayang (affection).

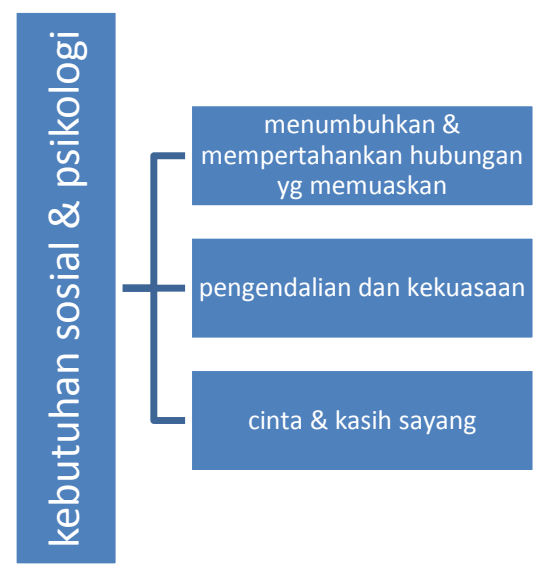

Kebutuhan Sosial \& psikologis manusia William Schultz 
Salah satu variabel paling penting dan paling banyak ditelaah dalam relasi interpersonal adalah daya tarik (attraction). Oleh karena itu relasi interpersonal akan diawali dengan ketertarikan antar pribadi yang mengembangkan suatu hubungan. Daya tarik menentukan menentukan sikap dan tindakan individu untuk membangun relasi atau tidak dengan individu lainnya. Individu akan memberikan penilaian atas individu lain sebagai diri yang menarik atau tidak. Kuatnya daya tarik seseorang akan mendorong orang lain membangun hubungan. Joseph A. De Vito (1997: 238241) mengklasifikasi beberapa kategori yang menentukan daya tarik;

1. Daya tarik fisik dan kepribadian; relasi interpersonal terjadi karena ketertarikan akan kondisi fisik dan perilaku yang ditunjukkan seseorang. Individu lebih kuat membangun relasi pada individu yang lain karena secara fisik dan kepridiannya menyenangkan. Sebaliknya individu tidak akan mengembangkan dan atau memutuskan relasi dengan individu lainnya, karena fisik dan kepribadiannya tidak menyenangkan.

2. Membentuk Citra (Impresi); merupakan upaya melekatkan karakteristik karakteristik positif kepada individu yang menurut seseorang menarik dan atau melekatkan karakteristik karakteristik negatif ketika seseorang dilihatnya tidak menarik. Upaya seperti ini dalam istilah yang lebih umum disebut dengan pencitraan.

3. Kedekatan (proksimitas); relasi interpersonal akan lebih mendalam ketika berlangsung pada area atau ruang yang berdekatan. Individu akan lebih dalam relasinya dengan individu lainnya karena kedekatan posisinya. Individu yang tinggal di suatu wilayah tertentu akan lebih dekat dengan orang di sekitarnya atau individu akan lebih dengan individu lainnya karena satu kantor tempat kerjanya. Kedekatan secara fisik antar personal memungkinkan mereka untuk mengenali satu dengan yang lainnya.

4. Pengukuhan; relasi interpersonal akan semakin mendalam terjadi ketika seseorang mendapatkan pengukuhan dari orang lain. Pengukuhan yang diberikan seseorang menunjukkan simpati mereka, sehingga hubungan akan lebih dekat terhadap individu yang mengukuhkan diri seseorang.

5. Menghargai orang lain; relasi interpersonal terjadi karena penghargaan seseorang atas orang lain. Individu individu yang dihargai akan lebih dihormati dalam relasi dengan individu lainnya. Penghargaan muncul karena kelayakan seseorang untuk mendapatkannya. 
6. Kesamaan; seseorang akan lebih suka mengembangkan relasi interpersonal karena adanya beberapa kesamaan karakteristik atau identitas pribadinya. Dalam kehidupan sehari - hari beberapa kesamaan yang menjadi dasar relasi meliputi; kebangsaan, agama, suku, budaya, daerah asal, kemampuan, fisik, umur, dan sikap serta selera.

7. Hipotesis kecocokan; tidak semua relasi interpersonal terbentuk karena kesaman -kesamaan, kecocokan seseorang atas orang lain bisa menjadi faktor penentu terbentuknya relasi interpersonal.

8. Sifat saling melengkapi (complementarity); kondisi masing masing individu seringkali tidak sama atau ada perbedaan. Ada yang memiliki kelebihan tertentu, tetapi memiliki kekurangan pada sisi yang lainnya. Relasi interpersonal seringkali terbentuk sebagai bagian dari upaya untuk saling melengkapi satu dengan yang lainnya. Kedekatan dan kedalaman hubungan seringkali karena kemampuan untuk saling melengkapi satu dengan yang lainnya.

Makna atau pentingnya relasi interpersonal bagi pelaku dan atau orang lain di sekitarnya sangat ditentukan oleh kualitas hubungan tersebut. Hubungan yang berkualitas akan memberikan makna yang baik, jika dibandingkan dengan kualitas yang rendah. Beberapa faktor yang menentukan kualitas relasi interpersonal diantaranya yaitu (Tubbs dan Moss.2001: 11-12)

1. Informasi tentang diri pihak yang akan diajak berelasi. Pada umumnya informasi tentang diri pihak yang akan diajak berelasi lebih bersifat psikologis daripada sosiologis dan kultural. Informasi diri secara psikologis harus dilakukan proses pendekatan mendalam, sehingga harus mengenali terlebih dahulu. Informasi yang bersifat sosiologis dan kultural tidak harus menggunakan pendekatan mendalam atau mengenali. Sumber informasi bisa datang dari pihak lain dan atau merupakan informasi yang bisa dinilai banyak orang.

2. Pengembangan aturan - aturan yang lebih banyak dilakukan oleh kedua pihak yang berelasi di dalamnya, bukan diatur oleh tradisi dari lingkungannya.

3. Peran yang dimainkan dalam relasi interpersonal lebih banyak ditentukan oleh karakteristik pribadi pihak yang mengembangkan relasi daripada oleh kondisi.

4. Relasi interpersonal yang berkualitas jika menekankan pilihan masing masing individu daripada pilihan kelompok. Pilihan individu terkait 
dengan pengetahuan mengenai sikap dan kepercayaan pribadi dan perilaku perilaku yang khas.

\section{Aspek Psikologi Komunikasi dalam Relasi Interpersonal}

Kepribadian merupakan aspek psikologis yang sangat penting dimiliki oleh individu. Pembentukan kepribadian manusia melalui proses yang berlangsung sepanjang hidup. Pembentukan kepribadian seseorang melalui proses relasi interpersonal dengan individu yang lain. Relasi yang ada terbangun melalui proses komunikasi dengan pihak lain. Tanpa ada komunikasi yang efektif pembentukan kepribadian seseorang akan gagal. Oleh karenanya komunikasi yang tercipta dalam relasi interpersonal membantu pertumbuhan kepribadian seseorang. Melalui komunikasi dalam relasi interpersonal seseorang akan menemukan jati dirinya, mengembangkan konsep diri, dan mampu mereposisi di lingkungan sekitarnya. Dinamika inilah yang menjadi aspek utama psikologi komunikasi dalam relasi interpersonal.

Sebuah studi longitudinal yang dilakukan Block selama satu dekade (19711981) diketahui bahwa beberapa ciri kepribadian menunjukkan konsistensi sepanjang waktu, terutama pada subjek penelitian berusia dewasa, sekitar 30 hingga 50 tahun.(Irwanto.2002: 246). Seiring dengan perubahan teknologi yang cepat seperti saat ini berakibat pada perubahan sosial kemasyarakatan, sekaligus perubahan individual. Oleh karenanya, situasi yang dihadapi seseorang bisa saja berubah secara drastis. Sebagaimana disebutkan Irwanto bahwa berbagai studi yang dilakukan dalam jangka pendek menunjukkan bahwa pola perilaku sangat situasional, konsistensi kecil. Dengan demikian, temuan tersebut memperkuat teori-teori kepribadian dari social learning. Meski demikian, kajian yang dilakukan pada kelompok yang lebih besar dalam waktu yang lebih panjang menghasilkan bukti-bukti yang menunjukkan bahwa kepribadian dalam diri seseorang cukup konsisten. Menurut Block, kalaupun ada perubahan yang cukup berarti, itu akan terjadi pada masa remaja (Irwanto.2002: 246).

Psikologi komunikasi merupakan proses atau peristiwa psikologis dalam diri masing-masing individu yang sedang membangun komunikasi di lingkungan dalam konteks relasi interpersonal dan atau intrapersonal. Psikologi komunikasi berupaya menganalisa seluruh komponen yang terlibat dalam proses komunikasi interpersonal dan atau intrapersonal. Dalam proses berkomunikasi ada dua pihak yang terlibat sesuai perannya yaitu; komunikan dan komunikator. Pada diri komunikan, psikologi komunikasi menganalisa karakteristik komunikan serta faktor-faktor 
internal maupun eksternal yang mempengaruhi perilaku komunikasinya. Pada diri komunikator, psikologi komunikasi mencoba melacak sifat-sifatnya dan bertanya: apa yang menyebabkan satu sumber komunikasi berhasil dalam mempengaruhi orang lain, sementara sumber komunikasi yang lain tidak.

Psikologi komunikasi merupakan sub disiplin ilmu dari Psikologi. Psikologi komunikasi adalah ilmu yang mempelajari komunikasi dari aspek psikologi. Disebut juga sebagai ilmu yang berusaha mendeskripsikan. memprediksikan, dan mengontrol mental dan perilaku, baik komunikasi yang dilakukan melalui komunikasi antar personal, komunikasi antar kelompok maupun komunikasi massa. (Siregar.2013: 28)

Jalaludin Rakhmat (1996: 7) menjelaskan bahwa komunikasi merupakan suatu hal yang penting bagi pertumbuhan kepribadian manusia. Karena kurangnya komunikasi akan menghambat perkembangan kepribadiannya. Psikologi menganalis seluruh komponen dalam suatu proses komunikasi. Psikologi meneliti pengalaman dan kesadaran manusia. Psikologi mencoba menyimpulkan kesadaran yang menyebabkan terjadinya perilaku manusia dan mengarahkan perhatiannya pada perilaku manusia. Psikologi komunikasi melihat bagaimana respon yang terjadi pada masa lalu dan dapat meramalkan respon yang akan terjadi pada masa yang akan datang.

Psikologi menganalisis seluruh komponen yang terlibat dalam proses komunikasi. Psikologi memberikan karakteristik manusia serta faktor-faktor internal maupun eksternal yang akan mempengaruhi perilaku komunikasi. Psikologi komunikasi diantara individu yaitu mengenai bagaimana pesan dari individu menjadi stimulus yang akan menimbulkan respon pada individu lainnya. Komunikasi bertujuan untuk memberikan suatu informasi, mempengaruhi, atau menghibur. Persuasif merupakan suatu proses mengendalikan dan mempengaruhi perilaku orang lain melalui suatu pendekatan psikologis.

Dalam konteks relasi interpersonal psikologi komunikasi akan berguna untuk memahami karakteristik personal atau kepribadian seseorang yang terlibat dalam relasi tersebut. Motif - motif yang melatarbelakangi terbangunnya relasi interpersonal akan lebih mudah terbaca, sehingga individu telah mendapatkan keuntungan atau sebaliknya akan diketahui. Dalam relasi interpersonal secara psikologi komunikasi akan muncul pola relasi yang beragam; relasi yang egaliter, relasi yang simetris, relasi yang asimetris (ada pihak yang dominan dan subordinat), relasi yang berkesinambungan, relasi yang bersifat sepotong - potong dan lain-lainnya. 
Muncul beragam pola tersebut ditentukan oleh kepribadian masing - masing pihak yang terlibat dalam relasi interpersonal.

Pendekatan psikologi komunikasi sangat berguna untuk mengembangkan bentuk - bentuk relasi interpersonal yang lebih konstruktif dan produktif, karena mengenali kepribadian masing - masing individu yang terlibat. Adanya pemahaman kepribadian masing - masing pihak, maka akan diketahui kelebihan dan atau kekurangannya serta potensi yang bisa dikembangkan dalam relasi interpersonal. Relasi interpersonal akan konstruktif dan produktif ketika masing - masing individu mengaktualisasikan dan atau mengekspresikan sisi positif kepribadiannya dan mengendalikan sisi negatifnya. Komunikasi yang efektif menjadi kunci utama dalam proses keduanya.

\section{Dinamika Relasi Interpersonal}

Relasi atau hubungan yang terjadi antara seorang dengan orang lain bukanlah sesuatu yang statis sifatnya. Jika mendasarkan pada tradisi sibernetika -dalam kajian Ilmu Komunikasi--, hubungan terdiri atas pola-pola sibernetika interaksi kata-kata dan perilaku seseorang memberi pengaruh pada bagaimana orang lain merespon. Dengan kata lain, pada umumnya manusia dapat menyesuaikan dengan situasi yang dihadapi dengan cara mempelajari pengalaman yang pernah dialami sebelumnya. Kita (manusia) terus mengubah apa yang kita lakukan dan apa yang kita percakapkan berdasarkan reaksi yang diberikan orang lain. Seiring dengan waktu hubungan, kemudian mengembangkan sebuah karakter individual.

Litllejohn dan Foss

(2014:284) menegaskan bahwa ketika dua orang saling berkomunikasi---selain apa pun yang mereka lakukan---mereka mengartikan hubungan mereka dengan cara mereka berinteraksi. Misalnya, ketika seseorang (A) berbicara dengan seorang temannya, anggota keluarganya, sahabatnya, atau gurunya, maka (A) selalu menciptakan sebuah dugaan untuk perilaku (A) sendiri dan perilaku orang lain. Kadang terjadi penguatan pada dugaan lama, pada waktu yang lain. Namun demikian bisa juga terjadi sebaliknya. Inilah yang menyebabkan kita pada umumnya terlibat dalam pola-pola interaksi baru yang dapat membentuk dugaan baru untuk interaksi pada waktu yang akan datang.

Seseorang membangun sebuah upaya komunikasi berdasarkan persepsi dan pemahaman mengenai beberapa aspek, seperti: apa yang menjadi tujuan dari relasi, bagaimana kualitas relasi yang diinginkan, kapan waktu yang tepat untuk menjalin relasi.Untuk mencapai tujuannya, komunikasi ataupun relasi interpersonal harus berjalan secara efektif dan efisien. Pada relasi yang dibangun antara seseorang 
dengan orang lainnya penting untuk direncanakan lebih dahulu. Untuk hasil yang baik, tidak boleh dilakukan sambil lalu, sebab hasil yang dicapai sulit diprediksi. Dengan begitu, seseorang perlu memahami betul siapa yang dihadapi, apa harapan masing-masing, dan bagaimana penyampaian pesan/topik yang dikomunikasikan.

Maksud dan tujuan komunikasi bermuara pada sebuah respon. Oleh karenanya seseorang yang ingin menyatakan pendapat atau menanggapi pendapat orang lain, perlu memeriksa dan mengukur apakah respon dari komunikannya memang sesuai dengan apa yang menjadi harapannya atau tidak. Itulah yang akhirnya menentukan proses komunikasi lebih lanjut. Misalnya keputusan apa yang selanjutnya harus diambil dan tindakan apa yang dilakukan untuk menguatkannya. Oleh sebab itu, perlu diketahui alasan utama apa yang menggerakkan orang-orang untuk berinteraksi. Lalu bagaimana seseorang "bergerak" kepada orang lain sambil mengungkapkan keinginan mereka untuk berteman dan bekerja sama. Di sisi lain terdapat fakta manusia lari dari manusia yang lain, menghindar dari berinteraksi dengannya, kecuali ketika kebutuhan mendesak. Hal ini menyangkut psikologi/ jiwa manusia. Lalu bagaimana komunikasi dalam hubungan yang sedang memburuk?
Hubungan yang memburuk disebabkan oleh pesan yang tidak tepat atau tidak baik. Namun demikian bias juga disebabkan karena cara kita berkomunikasi. De Vito (1997: 254) menyebutkan ada enam (6) pola pokok yang menandai komunikasi selama memburuknya hubungan, yaitu: 1) menarik diri 2) mengurangi pengungkapan diri 3) mengelabuhi 4) memberi evaluasi negatif 5) mengubah perilaku yang diharapkan, dan 6) kurang bertukar pujian.

Yusuf al Uqshary menyarankan perlunya memahami psikologi manusia sebab setiap orang mempunyai kepentingan dan jiwanya tidak boleh direndahkan (Uqshary. 2005:40). Agar seseorang bisa menjalin relasi interpersonal dengan baik dan dapat mempengaruhi orang lain perlu dilakukan hal berikut: pertama, menjaga sikap agar tidak merendahkan jiwa orang lain dari dekat ataupun jauh,(sebab kita semua mencintai diri kita). Kedua, perhatikanlah diri kita (ucapan, penampilan dan perilaku). Ketiga, berikan perhatian kepada orang lain dan emphaty betapa mereka penting. Keempat, agar diterima orang lain, maka terimalah diri mereka lebih dahulu.

Dalam dinamikanya, hubungan antar manusia yang awalnya face to face (bertemu muka secara langsung), kemudian memanfaatkan saluran atau yang dikenal dengan media (surat, hand phone, dll). Bahkan sampai saat ini hubungan terus 
berkembang dengan memanfaatkan media internet. Era kekinian merupakan zaman dimana semua orang bisa terhubung dengan internet. Migrasi manusia yang tinggi di zaman sekarang dari pulau ke pulau lain atau bahkan dari Negara satu ke Negara lain yang berbeda benua bisa terjadi. Keadaan ini tidak menjadi problem, sebab relasi interpersonal tetap bisa berjalan, dengan misalnya memanfaatkan skipe. Berbicara secara jelas dengan melihat komunikan langsung (serta suasana sekitarnya) tak sulit dilakukan, meski jarak ribuan kilometre menghadang.

Hampir semua bidang kehidupan seperti pendidikan, kesehatan, politik, maupun berbisnis, dilakukan dengan memanfaatkan media internet. Membangun kedekatan dengan orang lain selain dapat dilakukan secara darat juga bisa melalui dunia maya. Dengan jangkauan teknologi informasi dan social media yang semakin luas, maka relasi interpersonal memasuki dinamika baru. Teknologi, di satu sisi, memudahkan seseorang berkomunikasi, menyatakan ide dan perasan,serta mendapatkan feedback secara langsung, layaknya bertemu muka. Namun teknologi di sisi yang lain juga dapat menjadi ancaman bak pisau bermata dua yang akan berdampak negatif terhadap kepercayaan seseorang. Tentu saja hal tersebut terjadi jika tidak digunakan sebaik mungkin.

\section{KESIMPULAN}

Relasi interpersonal merupakan realitas sosial yang telah membangun dinamika kehidupan manusia menjadi lebih berwarna atau kompleks. Banyak kepentingan yang menyertai proses relasi interpersonal, baik kepentingan pihak - pihak yang mengembangkan relasi maupun orang lain di sekitarnya. Tidak semua relasi interpersonal berkembang dengan baik, banyak faktor mempengaruhi kualitas relasinya. Ada tahapan - tahapan yang harus dilalui agar relasi interpersonal mencapai kualitas yang tinggi. Kedua belah pihak yang terlibat dalam pengembangan relasi sangat menentukan tercapainya kualitas relasi. Aspek - aspek psikologis yang dimiliki kedua belah pihak yang terlibat dalam relasi lebih menentukan, daripada aspek sosiologis dan kultural. Kedekatan dalam relasi akan membantu meningkatkan kualitasnya. Pendekatan psikologi komunikasi sangat penting untuk memahami dinamika relasi interpersonal, dalam konteks konteks; psikologis dan komunikasi tentunya. Keduanya memiliki peranan penting dalam pengembangan relasi interpersonal menjadi lebih bermakna bagi pihak yang terlibat dan orang lain di sekitarnya.

\section{DAFTAR PUSTAKA}

Abadi, Totok Wahyu, dkk., Media Sosial dan Pengembangan Hubungan Interpersonal Remaja di Sidoarjo, 
Jurnal, KANAL, Vol. 2, No. 1, September 2013.

De Vito, Joseph A. 1997. Komunikasi Antarmanusia, terjemahan Agus Maulana, Jakarta : Profesional Books.

Idrus, Muhammad. Kompetensi Interpersonal Mahasiswa, Jurnal UNISIA, Vol. XXXII No. 72 Desember 2009.

Irwanto.2002. Psikologi Umum.Jakarta: Prenhallindo

Littlejohn, Stephen W dan Karen A. Foss. 2014. Theories of Human Communication (Teori

Komunikasi.edisi 9 ), terjemahan Muhammad Yusuf Hamdan, Jakarta: Salemba Humanika

Muhammad, Arni. 1995. Komunikasi Organisasi,Jakarta: Bumi Aksara.

Nurdin, Aminuddin.2016. Komunikasi dalam Praktik: Kreatif \& Bersahabat. Jakarta: Gagas Bisnis

Rakhmat, Jalaluddin. 1996. Psikologi Komunikasi, Bandung : PT. Remaja Rosdakarya.

Siregar, Lis Yulianti Syafrida, Peran Psikologi Komunikasi dalam Penerapan Nilai-nilai keIslaman di Keluarga, dalam Jurnal HIKMAH, Vol. VII, No.02 Juli 2013.

Teori Hubungan Interpersonal Heider lihat dalam http://jeffylouis.blogspot.co.id/2011/01/teorihubungan-interpersonalheider 2577.html Unduh, Minggu, 29 Januari 2017.

Tubs, Stewart L. dan Silvia Moss. 1996. Human Communiation Prinsip-prinsip Dasar, Terjemahan Deddy Mulyana, Edisi Kesatu, Bandung : PT Remaja Rosdakarya.

Tubbs, Stewart L., dan Sylvia Moss. 2001.

Human Communication, Terjemahan

Deddy Mulyana dan Gembirasari,
Edisi Kedua, Bandung : Remaja Rosdakarya.

Uqshary, Yusuf al. 2005. Menjadi Pribadi yang Berpengaruh. Jakarta: Gema Insani

Wahyuni, Akhtim. Mengasah Interpersonal Skills Mahasiswa Calon Pendidik, Jurnal PEDAGOGIA, Vol. 1, No. 1, Desember

2011. 